\title{
Early myocardial injury is an integral component of experimental acute liver failure - a study in two porcine models
}

\author{
Nikolaos Papoutsidakis ${ }^{1}$, Nikolaos Arkadopoulos ${ }^{1}$, Vassilios Smyrniotis ${ }^{1}$, Helen Tzanatos ${ }^{2}$, \\ Konstantinos Kalimeris ${ }^{3}$, Konstantinos Nastos ${ }^{1}$, George Defterevos ${ }^{1}$, Agathi Pafiti ${ }^{4}$, \\ Georgia Kostopanagiotou ${ }^{3}$
}

\author{
1Second Department of Surgery, Athens University School of Medicine, Aretaieion \\ Hospital, Athens, Greece \\ 2Department of Nephrology, Athens University School of Medicine, Aretaieion Hospital, \\ Athens, Greece \\ 3Second Department of Anaesthesiology, Athens University School of Medicine, Attikon \\ Hospital, Chaidari, Greece \\ 4Department of Pathology, Athens University School of Medicine, Aretaieion Hospital, \\ Athens, Greece
}

Submitted: 2 August 2010
Accepted: 7 September 2010

Arch Med Sci 2011; 7, 2: 217-223

DOI: 10.5114 /aoms.2011.22070

Copyright (c) 2011 Termedia \& Banach

\section{Abstract}

Introduction: There is accumulating clinical evidence that acute liver failure may be regularly associated with myocardial injury. To test this hypothesis in a standardized experimental setting, we used two porcine models of ALF.

Material and methods: In 14 domestic pigs ALF was induced by either a) surgical devascularization of the liver (DV group, $n=7$ ), or b) partial $(70-75 \%$ ) hepatectomy and ischaemia/reperfusion of the liver remnant for $150 \mathrm{~min}$ (I/R group, $n=7$ ). Four additional animals constituted the sham operation group. All animals were monitored for a 12-h period, at the end of which their hearts were harvested. Plasma troponin I (cTnl) and malondialdehyde (MDA) were measured before the operation (baseline) and at $6 \mathrm{~h}$ and $12 \mathrm{~h}$ postoperatively. The harvested hearts were histologically analysed, appointing a score from 0 (no injury) to 3 (maximum injury) to selected injury indicators.

Results: In the sham group, all cTnI measurements and total myocardial injury score were zero in all animals. In both ALF groups, plasma cTnl levels increased by the $6^{\text {th }}$ and remained elevated up to the $12^{\text {th }}$ postoperative hour $(p<0.01$ vs. sham animals). Total myocardial injury score and total histological score revealed some extent of myocardial injury. The rise of MDA levels suggests an underlying oxidative mechanism.

Conclusions: Our study provides direct evidence of early myocardial injury in the setting of acute liver failure in pigs. The mechanism of injury remains to be elucidated.

Key words: hepatectomy, troponin I, portacaval shunt.

\section{Introduction}

Multiorgan failure is a major complication of acute liver failure (ALF). Although circulatory disturbances which accompany acute liver failure were reported early on [1], direct effects upon the myocardium have not been studied, except for sporadic references of paracetamol overdose cases

\section{Corresponding author:}

Nikolaos Papoutsidakis MD

5 Miltiadou

Halandri, Greece

Phone: +30-6947006951

E-mail:

npapouts2@vodafone.net.gr 
accompanied by cardiac injury [2-4]. Recently, the US Acute Liver Failure Study Group [5] showed that elevations of serum troponin I (cTnl) levels are common ( $74 \%$ overall) in patients with ALF of various aetiologies. In the same study, higher troponin levels were associated with more severe clinical features and poorer outcomes. Despite the suspected high frequency of cardiac injury in ALF, very few experimental studies have examined the impact of liver injury upon the myocardium, mostly in the context of ischaemia-reperfusion injury [6-11]. Prompted by the clinical observation of the US Acute Liver Failure Study Group, we designed the present study using two different porcine models of surgically-induced liver failure in order to test the hypothesis that early myocardial injury is an integral part of ALF.

\section{Material and methods}

This study was approved by the Research and Bioethics Committee of our institution. All animals used in this study received humane care according to the criteria outlined in the "Guide for the Care and Use of Laboratory Animals", published by the National Institutes of Health.

Fourteen female Landrace pigs of mean weight $29.3 \mathrm{~kg}(28-32 \mathrm{~kg})$ were randomly assigned to two groups, the liver devascularization group (group DV, $n=7)$ and the liver ischaemia/reperfusion group (group I/R, $n=7$ ). Four additional animals constituted the sham operation (SH) group. Each animal was brought to the research facility at least 7 days prior to surgery, was housed separately and given free access to food and water. Twelve $h$ prior to surgery, feeding was discontinued and only free access to water was allowed.

\section{Anaesthesia and postoperative care}

Induction to anaesthesia was made with $4 \mathrm{mg} / \mathrm{kg}$ ketamine, $0.2 \mathrm{mg} / \mathrm{kg}$ midazolam and $0.5 \mathrm{mg}$ atropine administered intramuscularly, 30 min before general anaesthesia. The animal was secured in a supine position and a $20 \mathrm{G}$ catheter was placed in an ear vein. General anaesthesia was induced with iv thiopental sodium $5 \mathrm{mg} / \mathrm{kg}$ and ketamine $2 \mathrm{mg} / \mathrm{kg}$. The trachea was intubated with a cuffed tube of internal diameter of 5.5-6.0 mm and mechanical ventilation was started using a volume ventilator (Sulla 808 V, Dräger, Lübeck, Germany) with a fraction of inspired oxygen $\left(\mathrm{FiO}_{2}\right)$ of 0.4 , tidal volume of $10-12 \mathrm{ml} / \mathrm{kg}$ and respiratory rate of 10-15 breaths/min. A bolus dose of fentanyl $10-20 \mu \mathrm{g} / \mathrm{kg}$ and vecuronium bromide $0.5 \mathrm{mg} / \mathrm{kg}$ was given intravenously. Then, a nasogastric tube was inserted, the right external jugular vein was exposed and a central vein catheter 6.5 Fr (G986, Arrow International, Reading, PA, USA) was inserted to obtain central venous pressure measurements. The right femoral artery was cannulated with a $20 \mathrm{G}$ catheter for arterial pressure measurement. Intracranial pressure (ICP) was monitored using a subdural pressure transducer (Neuromonitor basic kit, Johnson and Johnson, Raynham, MA). Temperature was kept stable by means of a heating pad. Heart rate, arterial blood pressure, end tidal $\mathrm{CO}_{2}$, pulse oximetry and temperature were monitored continuously. Anaesthesia during the surgical procedure and throughout the monitoring phase was maintained with continuous intravenous infusion of fentanyl $15-20 \mu \mathrm{g} / \mathrm{kg} / \mathrm{h}$, ketamine $5-8 \mathrm{mg} / \mathrm{kg} / \mathrm{h}$ and vecuronium bromide $0.5 \mathrm{mg} / \mathrm{kg} / \mathrm{h}$. No volatile anaesthetics or vasoactive drugs were given. Intraoperatively and during the monitoring phase, dextrose $5 \%$ 20-100 $\mathrm{ml} / \mathrm{h}$, normal saline $100-300 \mathrm{ml} / \mathrm{h}$, colloids (Voluvent ${ }^{\circledR} 6 \%$, Fresenius Kabi, Germany) 50-150 ml/h and Ringer's lactated 100-300 ml/h were given as needed in order to maintain normoglycaemia, normal electrolytic values and the central venous pressure between $4 \mathrm{mmHg}$ and $9 \mathrm{mmHg}$.

After completion of $12 \mathrm{~h}$ of monitoring, the abdominal incision was reopened and the abdomen was explored for signs of surgical complications. Liver biopsies were also taken. The animals were then euthanised using i.v. infusion of propofol $1 \%$ $20 \mathrm{ml}$, vecuronium bromide $20 \mathrm{mg}$ and $\mathrm{KCl} 2 \mathrm{~g}$. Immediately after euthanasia, sternotomy was performed, the heart was harvested en bloc and $\mathrm{a} \sim 2 \times 2 \mathrm{~cm}$ piece of the left ventricular wall was obtained, at a distance of $2-4 \mathrm{~cm}$ from the apex.

\section{Surgical procedure}

Devascularization protocol (group DV): A midline abdominal incision was performed, followed by cystotomy and insertion of a Foley catheter in the bladder. An end-to-side portacaval anastomosis was then created with a 5-0 polypropylene suture and the hepatoduodenal ligament with its contents (hepatic artery, bile duct) was ligated and transected. This marks the beginning of the monitoring period. To ensure interruption of blood inflow from small collaterals, all other ligamentous attachments of the liver were also transected. The duration of the procedure was $60 \pm 12 \mathrm{~min}$. Total blood loss was $70 \pm 25 \mathrm{ml}$.

Ischaemia/reperfusion protocol (group I/R): A midline abdominal incision was performed, followed by cystotomy and insertion of a Foley catheter in the bladder. A side-to-side portacaval anastomosis was created using 5-0 polypropylene sutures. After completion of the anastomosis, the left hepatic artery was ligated and the hepatoduodenal ligament was clamped. A $65-70 \%$ hepatectomy was then performed by resection of the median and left liver lobes. The liver remnant was kept ischaemic for $150 \mathrm{~min}$ and then the 
portacaval anastomosis was clamped and blood flow was redirected to the liver remnant by unclamping the hepatoduodenal ligament. This time point marks the start of the monitoring period. The duration of the procedure - excluding the $150 \mathrm{~min}$ of ischaemia - was $65 \pm 15 \mathrm{~min}$. Total blood loss was $120 \pm 50 \mathrm{ml}$.

Animals in the sham-operation group underwent only laparotomy of 60 min duration.

\section{Blood and tissue sampling}

After placing the ear vein catheter (baseline sample) as well as at the time intervals of $6 \mathrm{~h}$ and $12 \mathrm{~h}$ of monitoring, blood samples were obtained, placed in anticoagulant-containing aliquots and centrifuged at $3500 \mathrm{rpm}, 4^{\circ} \mathrm{C}$ for $20 \mathrm{~min}$. The plasma was then immediately stored at $-80^{\circ} \mathrm{C}$. Twenty-four $\mathrm{h}$ blood samples were obtained immediately prior to euthanasia. Plasma samples were used to measure cTnl and malondialdehyde (MDA). Myocardial and liver biopsies were instantly fixed in 4\% formaldehyde/phosphate buffered saline and stored at room temperature. Later the samples were dehydrated and embedded in paraffin. Routine sections $(3-5 \mu \mathrm{m})$ were stained with haematoxylin-eosin. The rest of the heart was macroscopically inspected for possible infarct areas.

\section{Biochemical measurements}

cTnl measurement was done using the Dimension ${ }^{\circledR}$ system CTNI Flex ${ }^{\circledR}$ reagent cartridge kit (RF421C) (Dade-Behring, Greece). Reported sensitivity (from the manufacturer) is $0.04 \mathrm{ng} / \mathrm{ml}$. Cardiac troponin I use has been evaluated in pigs and was found both sensitive and specific for myocardial damage [12].

The malondialdehyde (MDA) concentration was determined in plasma samples spectrophotometrically at $586 \mathrm{~nm}$ and expressed in $\mathrm{nmol} / \mathrm{ml}$ using a commercially available kit (Oxford Biomedical Research, Oxford, MS, USA).

Briefly, $0.65 \mathrm{ml}$ of $10.3 \mathrm{mM} \mathrm{N}$-methyl-2-phenylindole in acetonitrile was added to $0.2 \mathrm{ml}$ of plasma. After vortexing for 3-4 $\mathrm{s}$ and adding $0.15 \mathrm{ml}$ of $\mathrm{HCl}$ $37 \%$, samples were mixed well, closed with a tight stopper and incubated at $45 \mathrm{~min}$ for $60 \mathrm{~min}$. The samples were then cooled on ice, centrifuged and the absorbance was measured spectrophotometrically at $586 \mathrm{~nm}$. A standard curve comprised of accurately prepared standard MDA solutions (from 2-20 $\mathrm{nmol} / \mathrm{ml}$ ) was also run for quantitation.

AST, ALT, LDH, urea, creatinine and $\mathrm{NH}_{3}$ were measured in the clinical laboratory.

\section{Histological examination}

Haematoxylin-eosin stained myocardium sections were blindly analysed by two pathologists simultaneously in a semi-quantitative manner, using 250x and 400x magnification under a light microscope. Approximately 25 fields of view (FOV) were examined under each magnification. Each specimen received a score from 0 to 3 , according to criteria outlined in Table I, for the following indicators: cell necrosis, presence of polymorphonucleocytes and eosinophils, loss of cross striation, oedema and microscopic bleeding. If more than one score criteria were met on the same slide (e.g. some FOV gave a score of 1 , others a score of 2 or 3 ) the highest score was appointed. The total histological score for each specimen was determined by the sum of all the partial scores.

\section{Statistical analysis}

Data are reported as mean \pm SD. Differences inside the same group for every parameter were analysed using one-way repeated measures ANOVA followed by the Bonferroni post hoc test. Differences between groups were analysed with ANCOVA using baseline values as the covariate. All statistical analyses were made with SPSS v.15.0 software; $p$ values $<0.05$ were considered statistically significant.

\section{Results}

All animals were maintained in good haemodynamic condition, with no statistically significant differences of mean arterial pressure (MAP) measurements between the baseline, 6-h and 12 -h time points of all groups (Figure 1 ). Also, haemoglobin values and renal function - as expressed by urea and creatinine - did not change significantly between the baseline and the $12^{\text {th }} \mathrm{h}$ in all groups (Table II).

Animals in both the DV and the I/R group developed ALF by the $6^{\text {th }} \mathrm{h}$ of monitoring, as evidenced by the intracranial hypertension, the significant increase in ammonia and the increase of markers of hepatocellular injury (Table II).

\section{Cardiac troponin I and MDA}

Baseline cTnl values were below the detection limit in all animals. No increase of cTnl above the detection limit was recorded in sham-operated animals, at either the $6^{\text {th }}$ or the $12^{\text {th }} \mathrm{h}$ time-point. In contrast, all ALF animals had increased cTnl values at both the $6^{\text {th }}$ and the $12^{\text {th }} \mathrm{h}$ time point ( $p<0.05$ compared to baseline). Differences between cTnl values of the DV and the I/R group were not statistically significant. Also the decrease of mean cTnl values recorded in both ALF groups between the $6^{\text {th }}$ and the $12^{\text {th }} \mathrm{h}$ measurement was not statistically significant (Table III). The malondialdehyde levels were significantly increased in DV 
Table I. Histological score

\begin{tabular}{|c|c|c|c|c|c|}
\hline & 0 & 1 & 2 & 3 & Magnification \\
\hline Necrosis & $\begin{array}{l}\text { None or } 1-3 \\
\text { dead cells in } \\
<3 \text { FOV }\end{array}$ & $\begin{array}{c}\leq 3 \text { dead cells } \\
\text { per FOV in at } \\
\text { least } 3 \text { FOV } \\
\text { or } 4-6 \text { cells in } \\
\text { no more than } \\
3 \text { FOV }\end{array}$ & $\begin{array}{c}4-6 \text { dead cells } \\
\text { per FOV in at } \\
\text { least } 4 \text { FOV } \\
\text { or }>6 \text { cells in } \\
\text { no more than } \\
3 \text { FOV }\end{array}$ & $\begin{array}{c}>6 \text { dead cells } \\
\text { in at least } \\
4 \text { FOV }\end{array}$ & $400 x$ \\
\hline $\begin{array}{l}\text { Polymorphonuclear } \\
\text { leucocytes }\end{array}$ & $\begin{array}{l}\text { None or 1-3 } \\
\text { cells in } \\
<3 \text { FOV }\end{array}$ & $\begin{array}{l}\leq 3 \text { cells } \\
\text { per FOV in at } \\
\text { least } 3 \text { FOV } \\
\text { or } 4-6 \text { cells } \\
\text { in no more } \\
\text { than } 3 \text { FOV }\end{array}$ & $\begin{array}{l}4-6 \text { cells } \\
\text { per FOV in at } \\
\text { least } 4 \text { FOV } \\
\text { or }>6 \text { cells } \\
\text { in no more } \\
\text { than } 3 \text { FOV }\end{array}$ & $\begin{array}{c}>6 \text { cells } \\
\text { in at least } \\
4 \text { FOV }\end{array}$ & $400 x$ \\
\hline Eosinophils & $\begin{array}{l}\text { None or 1-3 } \\
\text { cells in } \\
<3 \text { FOV }\end{array}$ & $\begin{array}{c}\leq 3 \text { cells } \\
\text { per FOV in at } \\
\text { least } 3 \text { FOV } \\
\text { or } 4-6 \text { cells } \\
\text { in no more } \\
\text { than } 3 \text { FOV }\end{array}$ & $\begin{array}{l}4-6 \text { cells } \\
\text { per FOV in at } \\
\text { least } 4 \text { FOV } \\
\text { or }>6 \text { cells } \\
\text { in no more } \\
\text { than } 3 \text { FOV }\end{array}$ & $\begin{array}{c}>6 \text { cells } \\
\text { in at least } \\
4 \text { FOV }\end{array}$ & $400 x$ \\
\hline Loss of striation & $\begin{array}{l}\text { None or } 1-5 \text { cells } \\
\text { in }<3 \text { FOV }\end{array}$ & $\begin{array}{l}\leq 5 \text { cells } \\
\text { per FOV in at } \\
\text { least } 3 \text { FOV } \\
\text { or } 5-10 \text { cells } \\
\text { in no more } \\
\text { than } 3 \text { FOV }\end{array}$ & $\begin{array}{l}5-10 \text { cells } \\
\text { per FOV in at } \\
\text { least } 4 \text { FOV } \\
\text { or }>6 \text { cells } \\
\text { in no more } \\
\text { than } 3 \text { FOV }\end{array}$ & $\begin{array}{c}>10 \text { cells } \\
\text { in at least } \\
4 \text { FOV }\end{array}$ & $400 x$ \\
\hline Oedema & None & $\begin{array}{c}<10 \% \text { of } \\
\text { FOV in at } \\
\text { least } 3 \text { FOV } \\
\text { or }>10 \% \\
\text { in }<3 \text { FOV }\end{array}$ & $\begin{array}{l}10-30 \% \text { of } \\
\text { FOV in at } \\
\text { least } 3 \text { FOV } \\
\text { or }>30 \% \\
\text { in }<3 \text { FOV }\end{array}$ & $\begin{array}{l}>30 \% \text { of } \\
\text { FOV in at } \\
\text { least } 3 \text { FOV }\end{array}$ & $250 x$ \\
\hline $\begin{array}{l}\text { Microscopic } \\
\text { bleeding }\end{array}$ & None & $\begin{array}{l}\text { Present in } \\
<10 \% \text { of } \\
\text { FOV in at } \\
\text { least } 3 \text { FOV } \\
\text { or }>10 \% \\
\text { in }<3 \text { FOV }\end{array}$ & $\begin{array}{l}\text { Present in } \\
10-30 \% \\
\text { of FOV in at } \\
\text { least } 3 \text { FOV } \\
\text { or }>30 \% \\
\text { in }<3 \text { FOV }\end{array}$ & $\begin{array}{c}\text { Present in } \\
>30 \% \text { of FOV } \\
\text { in at least } \\
3 \mathrm{FOV}\end{array}$ & $250 x$ \\
\hline
\end{tabular}

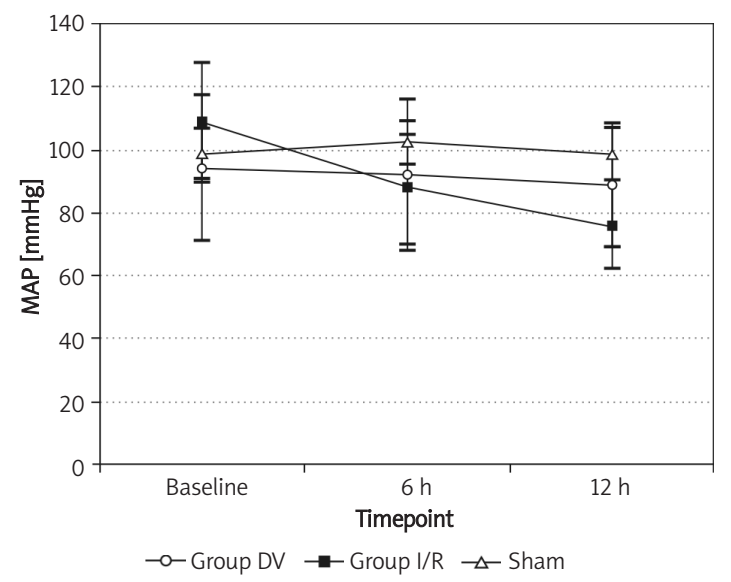

Figure 1. The differences of mean arterial pressure (MAP) measurements between the baseline, $6-\mathrm{h}$ and 12-h time points but not in I/R animals compared to the sham group at the $6^{\text {th }}$ and the $12^{\text {th }} \mathrm{h}$ time points (Table IV).

\section{Histological findings}

Haematoxylin-eosin stained liver sections revealed, in both groups, disorganization of hepatic lobules, widened portal spaces, inflammatory cell infiltration and dilated sinusoidal spaces. Haemorrhagic necrosis was also present in both groups but was more pronounced in DV animals (Figure 2). The histological scoring of myocardial injury for DV and I/R animals is presented in Table V. Myocardial cell necrosis and oedema were the most prominent changes. The total injury score in both the DV and the I/R group was significantly increased $(p<0.05)$ compared to the sham group, in which almost all animals received a score of 0 for all parameters 
(one animal received a score of 1 for microscopic oedema). Scoring differences between the DV and the I/R group were not statistically significant.

\section{Discussion}

Our study provides direct evidence of early myocardial injury in two different big-animal models of surgically induced ALF. All animals experienced a rise in troponin I as early as $6 \mathrm{~h}$ after the induction of ALF - a biochemical finding that corresponded to the histological alterations seen in myocardial biopsies obtained $12 \mathrm{~h}$ after the induction of ALF. This finding cannot be attributed to haemodynamic factors, since all animals were maintained in a good haemodynamic condition, with stable haemoglobin. Furthermore, the normal findings in sham-operated animals exclude anaesthesia, mechanical ventilation and invasive monitoring procedures as aetiological factors of myocardial injury.

For this study we selected two established surgical models of ALF which involve either complete liver devascularization (DV animals) or a combination of extensive hepatectomy with I/R injury of the small liver remnant (I/R animals). Both animal models have been shown in previous studies by our group and others $[13,14]$ to result in a rapid development of ALF, which is irreversible in DV animals and potentially reversible in I/R animals. We avoided toxin-induced ALF models because of poor reproducibility in large animals and the possible side effects of hepatotoxins on the myocardium.

An important observation in our study is the subtlety of myocardial injury. A histological score of 3 (the maximum for each histological parameter examined) was only once appointed, with all parameters ranging from 0 to 2 for each specimen. Necrotic cells were mostly dispersed with very little clustering (Figure 2). This indicates that the factor which caused cell death probably affected the whole heart and that it was not regional microcirculatory ischaemia, at least not per se. No necrotic, haemorrhagic or otherwise abnormal regions were observed macroscopically in any of the hearts.

The early appearance of cTnl in plasma and the fact that as time passed its levels did not rise indicates that cell necrosis must have started early on, before the $6 \mathrm{~h}$ time point in both protocols. This is confirmed by the study of Chen et al. [11]. cTnl can be detected in the bloodstream within minutes after cell damage [15]. Parekh et al. [5] report that $74 \%$ of patients with acute liver failure had elevated cTnl levels, while in our groups all animals (100\%) exhibited elevated cTnl levels. This discrepancy could be due to interspecies differences and a considerable heterogeneity of patient groups regarding the cause of acute liver failure.

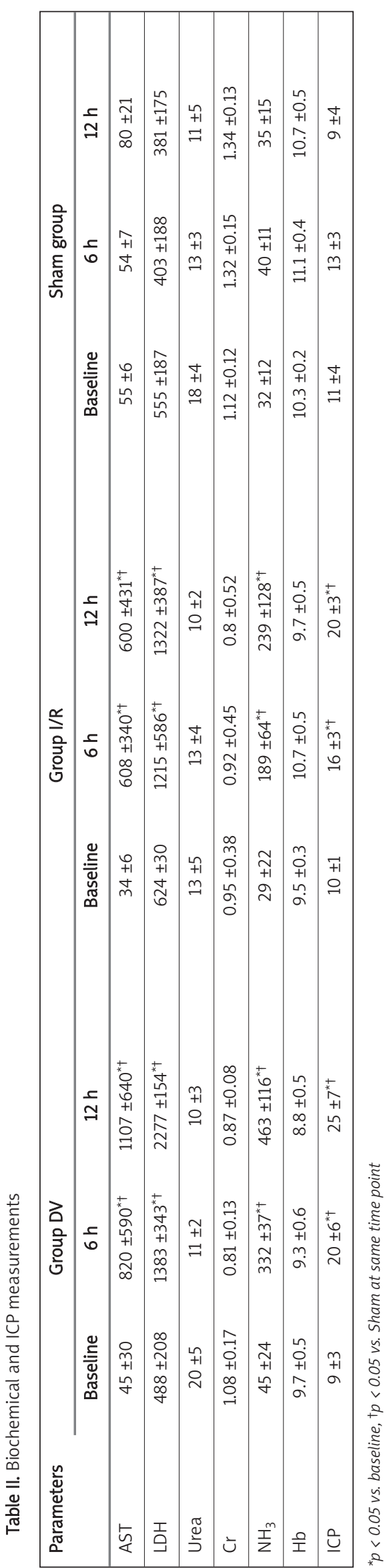


Table III. Troponin I (ng/ml)

\begin{tabular}{|lccccc|}
\hline Time point & $\begin{array}{c}\text { Group DV } \\
(\text { mean } \pm \text { SD })\end{array}$ & $\begin{array}{c}\text { Group I/R } \\
(\text { mean } \pm \text { SD })\end{array}$ & Sham group & \multicolumn{2}{c|}{$\begin{array}{c}\text { Statistical significance } \\
\text { between groups }(p)\end{array}$} \\
\cline { 4 - 6 } & & & DV vs. Sham & I/R vs. Sham \\
\hline Baseline & $<0.04$ & $<0.04$ & $<0.04$ & NS & NS \\
\hline $6 \mathrm{~h}$ & $1.40 \pm 0.91$ & $0.85 \pm 0.68$ & $<0.04$ & 0.025 & 0.044 \\
\hline $12 \mathrm{~h}$ & $0.93 \pm 0.44$ & $0.47 \pm 0.20$ & $<0.04$ & 0.007 & 0.002 \\
\hline
\end{tabular}

Table IV. MDA ( $\mathrm{nmol} / \mathrm{ml})$

\begin{tabular}{|lccccc|}
\hline Time point & $\begin{array}{c}\text { Group DV } \\
(\text { mean } \pm \text { SD })\end{array}$ & $\begin{array}{c}\text { Group I/R } \\
(\text { mean } \pm \text { SD })\end{array}$ & Sham group & \multicolumn{2}{c|}{$\begin{array}{c}\text { Statistical significance } \\
\text { between groups }(p)\end{array}$} \\
\cline { 4 - 6 } & & & DV vs. Sham & I/R vs. Sham \\
\hline Baseline & $1.88 \pm 0.07$ & $1.86 \pm 0.25$ & $1.59 \pm 0.26$ & NS & NS \\
\hline $12 \mathrm{~h}$ & $3.20 \pm 0.20$ & $1.69 \pm 0.48$ & $1.47 \pm 0.04$ & $<0.001$ & NS \\
\hline
\end{tabular}

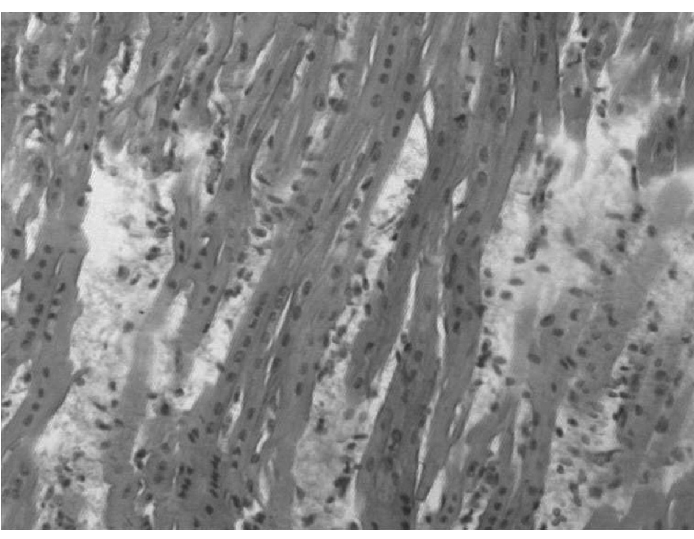

Figure 2. The presence of haemorrhagic necrosis in DV groups

During the experiments, we did not observe any arrhythmias or other major electrocardiographic abnormalities in any animal. This indicates that there was no major functional compromise of the heart.

There is little evidence to suggest a causative mechanism, or that there is a single mechanism involved in both our experimental groups. Cardiovascular collapse and sepsis, which could potentially be the cause of elevated cTnl levels in at least some humans with ALF [5], were not observed in our setting and therefore can be effectively ruled out. Oxidative stress is a possible candidate in the DV group, as indicated by the rise in plasma MDA. However, in the I/R group a similar rise is not seen. It is unclear whether this is due to lower levels of oxidative stress in this setting or to MDA kinetics. Early studies have shown that MDA is, mainly at least, metabolized by the liver $[16,17]$ and that it is rapidly eliminated [18]. If we accept that the main oxidative event in the I/R group was reperfusion,
Table V. Histological score

\begin{tabular}{|lcc|}
\hline & $\begin{array}{c}\text { Group DV } \\
(\text { mean } \pm \text { SD })\end{array}$ & $\begin{array}{c}\text { Group I/R } \\
(\text { mean } \pm \text { SD })\end{array}$ \\
\hline Necrosis & $1.25 \pm 0.5$ & $1 \pm 0.63$ \\
\hline $\begin{array}{l}\text { Polymorphonuclear } \\
\text { leucocytes }\end{array}$ & $0.75 \pm 0.5$ & $1.66 \pm 0.51$ \\
\hline Eosinophils & $0.25 \pm .5$ & $1 \pm 0.89$ \\
\hline Loss of striation & $0.75 \pm 0.5$ & $1.16 \pm 0.40$ \\
\hline Oedema & $1.25 \pm 0.95$ & $1.16 \pm 0.75$ \\
\hline Microscopic bleeding & $0.25 \pm 0.5$ & $0.5 \pm 0.83$ \\
\hline Total score & $4.5 \pm 1.73$ & $6.5 \pm 1.87$ \\
\hline
\end{tabular}

theoretically plasma MDA could have been metabolized by the remaining liver by the first 6 - $h$ time point. Parekh et al. [5] propose that the effect of high cytokine levels or other factors leading to multi-organ failure in humans could play a significant role. This is a plausible theory, but one would expect that, as ALF progresses, cTnl levels would continue to rise - a trend that was not observed in our setting. The basic limitation of our study is the lack of an in-depth investigation of the pathophysiological mechanisms involved in myocardial injury. In our opinion, oxidative mechanisms should be a primary target of future investigation. Serial heart biopsies and the use of anti-oxidants could be useful tools in such an investigation.

In conclusion, both our experimental models verify that myocardial injury is an integral part of experimental acute liver failure. However, the precise mechanisms leading to this injury, as well as possible targets for intervention, remain elusive. 


\section{Acknowledgments}

Financial Support: The project was co-funded by the European Social Fund and National Resources - (EPEAEK II) PYTHAGORAS.

\section{References}

1. Weston MJ, Talbot IC, Howorth PJ, Mant AK, Capildeo R, Williams R. Frequency of arrhythmias and other cardiac abnormalities in fulminant hepatic failure. Br Heart J 1976; 38: 1179-88.

2. Sanerkin NG. Acute myocardial necrosis in paracetamol poisoning. Br Med J 1971; 3: 478.

3. Wakeel RA, Davies HT, Williams JD. Toxic myocarditis in paracetamol poisoning. Br Med J 1987; 295: 1097.

4. Mann JM, Peirre-Louis M, Kragel PJ, Kragel AH, Roberts WC. Cardiac consequences of massive acetaminophen overdose. Am J Cardiol 1989; 63: 1018-21.

5. Parekh NK, Hynan LS, De Lemos J, Lee WM. Elevated troponin I levels in acute liver failure: is myocardial injury an integral part of acute liver failure? Hepatology 2007; 45: 1489-95.

6. Abraham R, Matza M, Marmor S, et al. Electromechanical impairment of human auricle and rat myocardial strip subjected to exogenous oxidative stress. Eur J Cardiothorac Surg 2003; 23: 66-73.

7. Weinbroum AA, Dembo G, Hochhauser E, Rudick V, Vidne BA. External pacing does not potentiate allopurinol protection of the heart from liver ischemia-reperfusion a study in an isolated perfused liver-heart rat model. Med Sci Monit 2001; 7: 1145-52.

8. Weinbroum AA, Kidron A, Hochhauser E, Hochman A, Rudick V, Vidne BA. Liver glutathione level influences myocardial reperfusion injury following liver ischemiareperfusion. Med Sci Monit 2001; 7: 1137-44.

9. Weinbroum AA, Hochhauser E, Rudick V, et al. Direct induction of acute lung and myocardial dysfunction by liver ischemia and reperfusion. J Trauma 1997; 43: 627-33.

10. Pretto EA. Cardiac function after hepatic ischemia-anoxia and reperfusion injury: a new experimental model. Crit Care Med 1991; 19: 1188-94.

11. Chen CF, Wang D, Lin HI, Leu FJ, Shen CY, Chou CC. Ischemia/reperfusion of the liver induces heart injury in rats. Transplant Proc 2007; 39: 855-7.

12. O'Brien PJ, Smith DE, Knechtel TJ, et al. Cardiac troponin I is a sensitive, specific biomarker of cardiac injury in laboratory animals. Lab Anim 2006; 40: 153-71.

13. Arkadopoulos N, Defterevos G, Papalois A, et al. Peritoneal albumin dialysis as a novel approach for liver support. Results in a porcine model of acute liver failure. J Hepatol 2009; 50 (Suppl 1): S57.

14. Van de Kerkhove MP, Hoekstra R, van Gulik TM, Chamuleau RA. Large animal models of fulminant hepatic failure in artificial and bioartificial liver support research. Biomaterials 2004; 25: 1613-25.

15. Bleier J, Vorderwinkler KP, Falkensammer J, et al. Different intracellular compartmentations of cardiac troponins and myosin heavy chains: a causal connection to their different early release after myocardial damage. Clin Chem 1998; 44: 1912-8.

16. Hjelle JJ, Petersen DR. Metabolism of malondialdehyde by rat liver aldehyde dehydrogenase. Toxicol Appl Pharmacol 1983; 70: 57-66.
17. Britton RS, O'Neill R, Bacon BR. Hepatic mitochondrial malondialdehyde metabolism in rats with chronic iron overload. Hepatology 1990; 11: 93-7.

18. Marnett LJ, Buck J, Tuttle MA, Basu AK, Bull AW. Distribution and oxidation of malondialdehyde in mice. Prostaglandins 1985; 30: 241-54. 